\title{
UJI EFEKTIVITAS ANTIDIABETES Eleutherine Bulbosa (MILL.) URB. TERHADAP PENURUNAN KADAR GLUKOSA DARAH TIKUS OBESITAS
}

\author{
Niluh Puspita Dewi ${ }^{1}$,*, Ramla Allia ${ }^{1}$, Sri Mulyani Sabang ${ }^{2}$ \\ ${ }^{1}$ Program Studi S1 Farmasi Sekolah Tinggi Ilmu Farmasi (STIFA) Pelita Mas Palu. \\ ${ }^{2}$ Jurusan Kimia FKIP Universitas Tadulako Palu \\ *Email: niluhpuspitadewi@ymail.com
}

\begin{abstract}
ABSTRAK
Ekstrak umbi bawang dayak (Eleutherine bulbosa (Mill.) Urb.) mengandung senyawa kimia yaitu alkaloid, flavonoid, saponin, tanin dan fenolik yang diduga berpotensi sebagai antidiabetes. Penelitian ini bertujuan untuk mengetahui efek antidiabetes dari ekstrak etanol umbi bawang dayak terhadap tikus putih jantan (Rattus norvegicus) diabetes melitus tipe 2 yang obesitas dan mengetahui dosis yang efektif sebagai antidiabetes. Metode penelitian yang digunakan adalah metode eksperimen laboratorium yang dilakukan dengan pengukuran kadar glukosa darah sebelum dan sesudah induksi streptozotocin. Penelitian ini menggunakan tikus putih jantan yang dibagi dalam 6 kelompok perlakuan. Kelompok 1 sebagai kontrol normal, kelompok 2 diberikan Na-CMC sebagai kontrol negatif, kelompok 3 diberikan suspensi metformin sebagai kontrol positif, dan kelompok 4, 5, 6 menggunakan ekstrak etanol bawang dayak dengan variasi dosis 500, 750, $1000 \mathrm{mg} / \mathrm{kg} \mathrm{BB}$. Tikus diinduksi pakan tinggi lemak selama 4 minggu dan dilanjutkan induksi streptozotocin. Perlakuan diberikan per oral selama 14 hari. Data hasil pengamatan dianalisis secara statistik dengan Analisis Sidik Ragam dan dilanjutkan dengan uji Duncan. Hasil menunjukkan bahwa ekstrak umbi bawang dayak dosis $500 \mathrm{mg} / \mathrm{kg}$ BB merupakan dosis yang paling efektif dalam penurunan kadar glukosa darah.
\end{abstract}

Kata kunci : Antidiabetes, Ekstrak umbi bawang dayak (Eleutherine bulbosa (Mill.) Urb.), Streptozotocin.

\begin{abstract}
Bawang dayak (Eleutherine bulbosa (Mill.) Urb.) contains chemical compounds are alkaloids, flavonoids, saponins, tannins and phenolic alleged potential as an antidiabetic. The purpose of this research wash to determine the antidiabetic effect of the ethanol extract of bawang dayak bulb. Against male rats (Rattus norvegicus) that are obese type 2 diabetes mellitus and determine the effective dose as an antidiabetic. The method used is the laboratory experiments were conducted by measuring blood glucose levels before and after induction of streptozotocin. This study used male rats were divided into six treatment groups. Group 1 as the normal control, group 2 was given Na-CMC as a negative control, group 3 was given the suspension of metformin as a positive control, and group 4, 5, 6 using the ethanol extract of bawang dayak with variations dose of 500, 750, $1000 \mathrm{mg} / \mathrm{kg}$ weight. Induced mice a high-fat feeding for 4 weeks and continued induction of streptozotocin. The treatment was given orally for 14 days. The data were statistically analyzed with analysis Sidik Variety and Duncan test. The results showed that the etanolic extracts of bawang dayak bulb dose of $500 \mathrm{mg} / \mathrm{kg}$ weight dose was the most effective in decreasing blood glucose levels.
\end{abstract}

Keywords : Antidiabetic, Eleutherine bulbosa (Mill) Urb., Streptozotocin . 


\section{PENDAHULUAN}

Pola gaya hidup yang tidak tepat yaitu dengan mengkonsumsi makanan tinggi lemak, kurang gerak, stres yang dialihkan dengan makan menyebabkan orang menjadi obesitas. ${ }^{1}$ Pada obesitas kemungkinan terkena diabetes melitus 2,9 kali lebih sering bila dibandingkan yang tidak obesitas. ${ }^{2}$ Riset Kesehatan Dasar (RIKESDAS) pada tahun 2013 yang menyatakan penderita diabetes melitus sebanyak $2,1 \%$ dari tahun ke tahun, sedangkan untuk daerah Sulawesi Tengah prevalensi penderita diabetes melitus untuk gejala dan diagnosanya menempati peringkat pertama yaitu sebanyak $3,7 \%$. ${ }^{3}$ Penyakit diabetes melitus ditandai dengan hiperglikemia kronik sebagai akibat disfungsi kerja insulin. Diabetes melitus terdiri atas dua tipe yaitu diabetes melitus tipe 1 dan diabetes melitus tipe $2 .^{4}$

Diabetes Melitus yang paling banyak diderita adalah diabetes melitus tipe 2 yaitu penyakit gangguan metabolik yang ditandai oleh kenaikan gula darah akibat penurunan sekresi insulin oleh sel beta pankreas dan atau gangguan fungsi insulin (resistensi insulin). ${ }^{5}$ Diperkirakan pada tahun 2025 akan terdapat 300 juta pasien diabetes melitus tipe 2 di seluruh dunia. ${ }^{6}$ Melihat bahwa diabetes melitus akan memberikan dampak terhadap kualitas sumber daya manusia, dan peningkatan biaya kesehatan yang cukup besar, maka sangat diperlukan program pengendalian diabetes melitus tipe 2. Diabetes melitus tipe 2 bisa dicegah, ditunda kedatangannya atau dihilangkan dengan mengendalikan faktor resiko. ${ }^{7}$ Penelitian-penelitian yang telah dilakukan sebelumnya menyatakan bahwa demografi, faktor perilaku dan gaya hidup, serta keadaan klinis atau mental berpengaruh terhadap kejadian diabetes melitus tipe $2 .^{8}$

Banyak cara dapat dilakukan untuk mencegah maupun memperlambat progres penyakit diabetes melitus, baik dengan obat-obatan maupun dengan mengubah pola gaya hidup menjadi lebih sehat. Salah satunya dengan mengonsumsi pangan fungsional yang mengandung satu atau lebih senyawa metabolisme seperti (flavonoid, alkaloid, glikosida, fenolik, saponin, triterpenoid, tanin, steroid dan kuinon) yang terbukti dapat membantu menjaga kadar gula darah dalam kisaran normal. ${ }^{9}$ Tanaman yang mengandung metabolit sekunder banyak dimanfaatkan sebagai tanaman obat tradsional. Hal ini disebabkan karena kandungan metabolit sekunder memiliki banyak manfaat dan keuntungan terutama bagi kesehatan manusia. Selain itu juga tanaman yang mengandung metabolit sekunder mudah didapat dan memiliki efek samping yang relatif kecil dibandingkan obat kimiawi. ${ }^{10}$

Pengobatan secara tradisional telah digunakan secara turun temurun sejak dari zaman dulu berdasarkan adat istiadat, kepercayaan, dan kebiasaan setempat. Dekade terakhir ini banyak penelitian yang ditujukan untuk pengembangan tanaman sebagai sumber bahan obat. Sekitar $75 \%-80 \%$ penduduk di dunia menggunakan bahan obat yang berasal dari tumbuh-tumbuhan, dan sekitar $28 \%$ dari tumbuhan di bumi telah dipakai sebagai bahan obat tradisional. ${ }^{11}$ Indonesia merupakan salah satu negara pengguna obat tradisional terbesar di dunia bersama negara lain di Asia seperti Cina dan India, hal ini erat kaitannya dengan kekayaan sumber alam hutan tropis yang dimiliki Negara Indonesia dan keragaman budaya yang terpelihara sampai saat ini. ${ }^{12}$

Salah satu tanaman obat yang banyak digunakan oleh masyarakat khususnya masyarakat Sulawesi Tengah sebagai obat adalah Bawang dayak (Eleutherine bulbosa (Mill.) Urb.). Tanaman ini sudah dipergunakan secara turun temurun oleh masyarakat sebagai tanaman obat. ${ }^{13}$ Bawang dayak memiliki daun berwarna hijau dengan bunga berwarna putih serta umbi berwarna merah yang menyerupai bentuk umbi bawang merah. Air rebusan atau perasan umbi bawang dayak secara tradisional diyakini mempunyai berbagai khasiat, antara lain sebagai obat kanker payudara, darah tinggi, kencing manis, kolestrol, dan bisul. ${ }^{14}$ Kandungan yang terdapat dalam bawang dayak terdiri dari senyawa alkaloid, glikosida, flavonoid, fenolik, saponin, triterpenoid, tanin, 
steroid dan kuinon yang merupakan sumber biofarmaka yang berpotensial untuk dikembangkan sebagai tanaman obat modern dalam kehidupan manusia. ${ }^{15}$

Penelitian terdahulu menyimpulkan bahwa hasil penapisan fitokimia dan perhitungan total flavonoid dan total fenol pada ekstrak umbi bawang dayak memperlihatkan jenis dan kandungan senyawa fitokimia yang lebih besar pada ekstrak etanol dibandingkan pada ekstrak air. Perpaduan kapasitas antioksidan dan kemampuan penghambatan enzim alfa glukosidase yang terdapat pada umbi bawang dayak menunjukkan bahwa umbi bawang dayak memiliki potensi sebagai antidiabetik yang bermanfaat dalam pencegahan dan perlindungan terhadap penyakit diabetes melitus. ${ }^{16}$ Sedangkan penelitian lainnya menyimpulkan bahwa pemberian ekstrak bawang dayak tidak menurunkan kadar glukosa darah pada mencit Swiss Webster dengan dosis $100 \mathrm{mg} / \mathrm{kgBB}, 200 \mathrm{mg} / \mathrm{kg} \mathrm{BB}$, dan 400 $\mathrm{mg} / \mathrm{kgBB} .{ }^{17}$

Berdasarkan masalah tersebut, peneliti ingin mengetahui apakah ekstrak etanol umbi bawang dayak memiliki efektivitas antidiabetes pada diabetes melitus tipe 2 yang obesitas dan pada dosis berapa yang efektif sebagai antidiabetes pada diabetes melitus tipe 2 . Tujuan dari penelitian ini yaitu untuk mengetahui efek antidiabetes dari ekstrak etanol umbi bawang dayak terhadap tikus putih jantan diabetes melitus tipe 2 yang obesitas dan mengetahui dosis yang efektif sebagai antidiabetes. Manfaat penelitian diharapkan dapat memberikan informasi pada masyarakat mengenai khasiat yang terkandung dalam umbi bawang dayak yang bisa digunakan sebagai tanaman obat antidiabetes yang tidak kalah berkhasiat dengan obat kimiawi yang sering digunakan pada masyarakat umumnya.

Data dikumpulkan dari hasil penelitian dengan menggunakan 30 ekor tikus putih yang dibagi 6 kelompok perlakuan. Kelompok 1 sebagai kontrol normal, kelompok 2 diberikan Na-CMC sebagai kontrol negatif, kelompok 3 diberikan suspensi metformin sebagai kontrol positif, dan kelompok 4, 5, 6 menggunakan ekstrak etanol bawang dayak dengan variasi dosis 500, 750, $1000 \mathrm{mg} / \mathrm{kg} \mathrm{BB}$. Metode yang digunakan adalah metode eksperimen laboratorium yang dilakukan dengan pengukuran kadar glukosa darah sebelum dan sesudah induksi streptozotocin dosis rendah $(30 \mathrm{mg} / \mathrm{kg} \mathrm{BB})$. Hasil pengamatan yang diperoleh dianalisis secara statistik Analisis Sidik Ragam dengan taraf kepercayaan $95 \%$. Jika terdapat perbedaan yang signifikan maka dilakukan uji lanjut sesuai nilai koefisien keragaman (KK) data yang diperoleh.

\section{METODE PENELITIAN}

Penelitian ini adalah penelitian eksperimen laboratorium dengan menggunaka Rancangan Acak Kelompok (RAK) dimana kelompok 1 sebagai kontrol normal, kelompok 2 diberikan Na-CMC sebagai kelompok kontrol negatif, kelompok 3 diberikan suspensi metformin sebagai kelompok kontrol positif/pembanding, dan kelompok 4, 5, 6 menggunakan ekstrak etanol umbi bawang dayak dengan masing-masing dosis 500, 750, $1000 \mathrm{mg} / \mathrm{kg} \mathrm{BB}$.

\section{Bahan}

Bahan yang digunakan antara lain Aquadest, asam klorida, alkohol 70\%, etanol 96\%, Ekstrak umbi bawang, $\mathrm{FeCl}_{3}$, Hewan uji tikus putih jantan, Handskun, kapas, magnesium $\mathrm{P}$, metformin $500 \mathrm{mg}, \mathrm{Na} \mathrm{CMC} \mathrm{0,5 \% ,} \mathrm{NaCl,} \mathrm{Pakan} \mathrm{tinggi} \mathrm{lemak} \mathrm{(Lemak} \mathrm{sapi,}$ kuning telur bebek, minyak kelapa), Pakan standar, Pereaksi Dragendorff dan Streptozotocin.

\section{Peralatan}

Alat yang digunakan antara lain ayakan mesh no.40, batang pengaduk, bejana maserasi, blender, cawan porselin, corong gelas, erlenmeyer, gegep kayu, gelas kimia 50 
ml, gelas ukur $100 \mathrm{ml}$, glucometer (Easy Touch), glucotest strips (Easy Touch, kandang hewan uji, lumpang dan alu, lap kasar, penangas air, pipet tetes, rotary vacuum evaporator (Eyela), rak dan tabung reaksi, sonde oral, spoit injeksi $3 \mathrm{ml}$ dan $1 \mathrm{ml}$, tabung reaksi, timbangan analitik, timbangan digital dan wadah ekstraksi.

\section{Prosedur}

Prosedur penelitian merupakan serangkaian kegiatan yang dilaksanakan oleh seorang peneliti secara teratur dan sistematis untuk mencapai tujuan-tujuan peneliti. Penguraian semua langkah penelitian dirangkai menjadi suatu prosedur penelitian yang utuh, mulai dari perencanaan atau persiapan tindakan yang dilakukan dalam rangka pelaksanaan penelitian.

\section{Pengambilan dan Pengolahan Bahan}

Bahan yang digunakan adalah umbi bawang dayak yang diperoleh dari dataran tinggi Mantantimali, Kota Palu. Bahan yang diambil, dikumpulkan kemudian disortasi basah untuk memisahkan bagian tanaman yang tidak dibutuhkan, lalu dicuci dengan air mengalir sampai bersih. Selanjutnya dilakukan perajangan dan dikeringkan dengan cara diangin-anginkan tanpa terkena sinar matahari langsung hingga bahan tersebut mengering. Selanjutnya dilakukan sortasi kering untuk memisahkan benda-benda asing yang masuk pada saat pengeringan. Sampel yang telah kering dihaluskan menggunakan blender dan diayak dengan ayakan mesh no.40. Lalu simplisia siap untuk diekstraksi.

\section{Pembuatan Ekstrak Etanol Bawang Dayak}

Bawang dayak sebanyak 650 gram diekstraksi dengan metode maserasi yaitu dengan cara memasukkan sampel dalam suatu bejana lalu merendam sampel dalam etanol (96\%) sampai $2 \mathrm{~cm}$ di atas permukaan sampel, diaduk lalu didiamkan selama 5 hari untuk proses ekstrak yang sempurna sambil diaduk sekali-kali. Disaring untuk mendapatkan ekstrak etanol, lalu dipekatkan dengan menggunakan alat rotavapor selanjutnya diuapkan di atas penangas air hingga diperoleh ekstrak kental.

\section{Uji Penapisan Fitokimia}

Penapisan kandungan kimia dilakukan berdasarkan metode analisis tanaman antara lain pengujian alkaloid, saponin, flavonoid, tannin dan fenolik untuk dapat mengetahui golongan senyawa kimia yang dikandung tumbuhan yang sedang diteliti.

\section{Pembuatan Larutan Koloidal Na-CMC 0,5 \% b/v}

Larutan kolodial Na-CMC 0,5\% dibuat dengan melarutkan 0,5 gram Na-CMC sedikit demi sedikit ke dalam $50 \mathrm{ml}$ air suling panas sambil diaduk hingga larutan koloid. Volume dicukupkan hingga $100 \mathrm{ml}$ dengan air suling.

\section{Pembuatan Suspensi Metformin}

Dosis metformin pada manusia dewasa adalah $500 \mathrm{mg}$ per hari, jika dikonversi pada tikus dengan berat $200 \mathrm{~g}$ adalah 0,018 maka dosis metformin untuk tikus adalah $9 \mathrm{mg} / \mathrm{kg}$ BB. Ditimbang serbuk tablet metformin yang setara dengan $360 \mathrm{mg}$ kemudian disuspensi dalam $\mathrm{Na}$ CMC 0,5\% hingga $100 \mathrm{ml}$.

\section{Pembuatan Larutan Induksi Streptozotocin}

Ditimbang streptozotocin dan dilarutkan menggunakan $\mathrm{NaCl} 0,9 \%$ kemudian diinduksikan pada tikus melalui intraperitoneal (ip). Dosis streptozotocin yakni $30 \mathrm{mg} / \mathrm{kg}$ BB. 


\section{Pembuatan Pakan Tinggi Lemak}

Makanan tinggi lemak yang digunakan pada penelitian ini adalah makanan berupa pellet yang ditambahkan kuning telur bebek, lemak sapi dan minyak kelapa. Pakan yang dibutuhkan untuk 25 ekor tikus selama 14 hari $\pm 7 \mathrm{~kg}$. Cara mempersiapkan pakan tinggi lemak yaitu pertama-tama memanaskan lemak sapi hingga mencair atau menjadi minyak. Kedua, telur direbus hingga matang, dipisahkan kuning telur dengan putih telur, dikeringkan kuning telur dengan suhu $60^{\circ} \mathrm{C}$ selama 2 jam didalam oven dan telur sudah siap untuk dicampur.

Bahan-bahan yang telah disiapkan dicampur dengan cara meletakkan pellet pakan standar dalam sebuah wadah yang telah disediakan. Dituang minyak sapi (minyak masih dalam kondisi panas) diaduk dan dibiarkan selama 20 menit. Ditambahkan air, diaduk dan ditunggu selama kurang lebih 1 jam hingga pakan lembut dan mudah untuk dicampur. Ditambahkan minyak kelapa ke dalam adonan dan diaduk kembali hingga rata. Ditambahkan kuning telur yang sudah dikeringkan ke dalam adonan sedikit demi sedikit sambil diaduk hingga bahan-bahan tersebut diatas tercampur dengan rata. Seluruh adonan dibentuk dengan panjang kurang lebih $3 \mathrm{~cm}$ dengan diameter $0,5 \mathrm{~cm}$, diletakkan diatas seng dan dikeringkan langsung di bawah sinar matahari hingga kering. Jumlah konsumsi makanan setiap harinya maksimum sebanyak $20 \mathrm{~g} /$ tikus dan diberikan selama 2 minggu.

\section{Pemilihan Hewan Uji}

Hewan uji yang digunakan sebanyak 30 ekor tikus (Rattus norvegicus) yang memiliki kriteria inklusi yaitu tikus putih jantan jenis wistar, berumur 2-3 bulan, berat badan 150-250 gram, berbulu putih, sehat dan tidak cacat secara anatomi, sedangkan kriteria eksklusi yaitu tikus sakit, cacat, mati sebelum mendapat perlakuan dan selama perlakuan, serta ditempatkan di kandang.

\section{Perlakuan Terhadap Hewan Uji}

1. Langkah I :

Penelitian menggunakan hewan uji sebanyak 30 ekor tikus jantan dibagi menjadi 6 kelompok, diadaptasikan selama 14 hari dan diberi pakan standar dan minum.

2. $\quad$ Langkah II :

Setelah diadaptasikan, 30 ekor tikus jantan ditimbang bobot badan lalu dipuasakan selama 16 jam dan diukur kadar glukosa darah awal.

3. Langkah III :

Setelah dilakukan pemeriksaan awal kadar glukosa darah, tikus diinduksi pakan tinggi lemak selama 4 minggu dan dilanjutkan induksi streptozotocin dengan dosis 30 $\mathrm{mg} / \mathrm{kg}$ BB kecuali kelompok normal

4. Langkah IV :

Setelah diinduksi pakan tinggi lemak dan streptozotocin, tikus diukur berat badan dan kadar glukosa darahnya setiap hari hingga menunjukkan kadar glukosa darah puasa tikus diatas $200 \mathrm{mg} / \mathrm{dL}$ dan telah obesitas.

6. $\quad$ Langkah VII :

Setelah dilakukan pengukuran berat badan kadar glukosa darah, 6 kelompok tikus diberi perlakuan per oral selama 14 hari.

Kelompok 1 : Kelompok normal, tidak diberi Na CMC dan tidak di induksi.

Kelompok 2 : Diberikan suspensi Na CMC sebagai kontrol negatif.

Kelompok 3 : Diberikan suspensi metformin sebagai kontrol positif.

Kelompok 4 : Diberikan ekstrak etanol umbi bawang dengan dosis masing-masing 500 $\mathrm{mg} / \mathrm{Kg} \mathrm{BB}$

Kelompok 5 : Diberikan ekstrak etanol umbi bawang dayak dengan dosis masing- 
masing $750 \mathrm{mg} / \mathrm{Kg} \mathrm{BB}$

Kelompok 6 : Diberikan ekstrak etanol umbi bawang dengan dosis masing-masing

7. Langkah VIII : $1000 \mathrm{mg} / \mathrm{Kg} \mathrm{BB}$

Setelah perlakuan, dilakukan pemeriksaan kadar glukosa darah tikus jantan yang sebelumnya telah dipuasakan selama 16 jam.

8. $\quad$ Langkah XI :

Semua data kadar glukosa sebelum dan setelah perlakuan yang diperoleh, ditabulasi, dibuat rata-rata dan dianalisis.

\section{Penentuan Obesitas}

Hewan uji tikus putih jantan (Rattus norvegicus) diukur berat badan dan panjangnya. Obesitas tikus ditentukan berdasarkan indeks obesitas Lee $^{64}$. Tikus dinyatakan obesitas jika nilai indeks obesitas Lee $>0,3$. Indeks obesitas Lee dihitung dengan rumus :

Indeks Obesitas Lee $=\frac{\sqrt{\text { Berat Badan (gram)x 10 }}}{\text { Panjang Nasoanal (mm) }}$

\section{Penentuan Kadar Glukosa Darah}

Glucotest (Easy Touch) dihidupkan dan stik glukosa dimasukkan ke dalam glucotest. Darah diambil melalui ujung ekor kemudian diteteskan pada stik glucotest, dalam waktu 10 detik kadar glukosa darah akan terukur secara otomatis dan hasilnya dapat dibaca pada monitor dalam satuan $\mathrm{mg} / \mathrm{dL}$. Mekanisme kerja dari alat glucotest ini yaitu kerjanya secara enzimatik melibatkan reaksi glukosa oksidase, reaksi ini menghasilkan intensitas warna yang dideteksi oleh alat ini.

\section{Analisa Data}

Data hasil pengamatan yang diperoleh dianalisis menggunakan Rancangan Acak Kelompok (RAK) dan dianalisis secara statistik dengan Analisis Sidik Ragam (ANSIRA) dengan taraf kepercayaan 95\%. Uji ini digunakan untuk menentukan apakah ada perbedaan yang signifikan antar perlakuan. Jika terdapat perbedaan yang signifikan maka dilakukan uji lanjut sesuai nilai koefisien keragaman (KK) data yang diperoleh.

\section{HASIL DAN PEMBAHASAN}

\section{Hasil Pengamatan}

Hasil pengukuran kadar glukosa darah tikus putih jantan (Rattus norvegicus) sebelum perlakuan, setelah induksi streptozotocin dan setelah pemberian ekstrak etanol umbi bawang dayak dapat dilihat pada grafik berikut. 


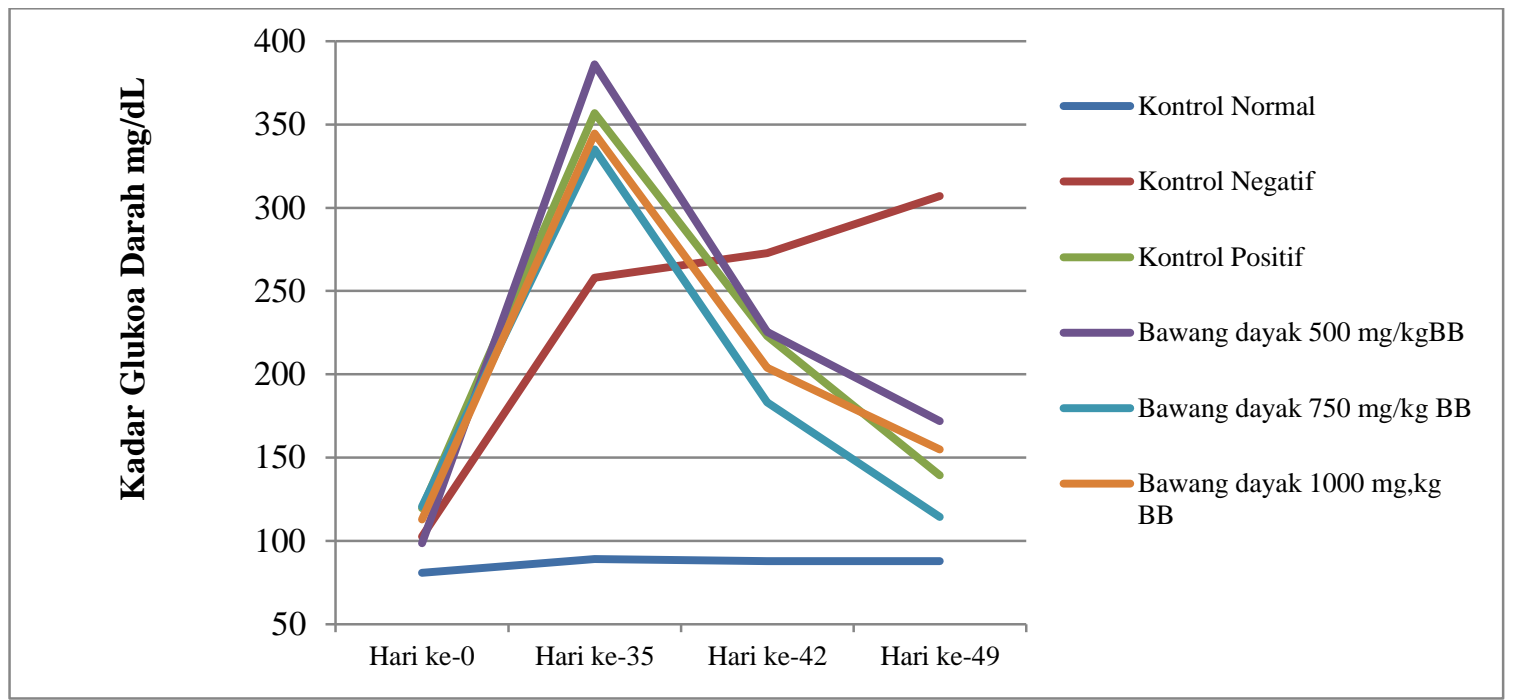

Gambar 1. kadar glukosa darah tikus putih jantan sebelum perlakuan, setelah induksi dan selama perlakuan

Profil penurunan kadar glukosa darah masing-masing kelompok perlakuan dapat dilihat pada grafik dibawah ini:

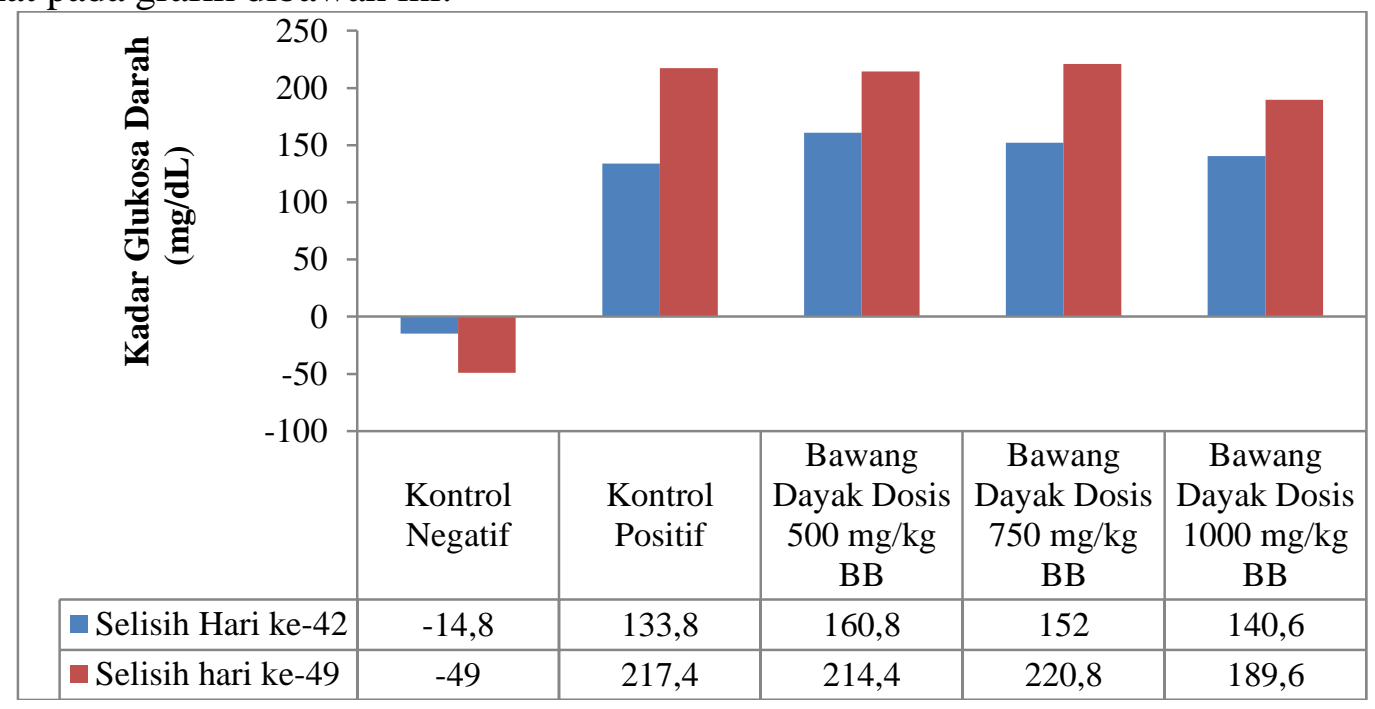

\section{Keterangan :}

Gambar 2. Grafik Selisih Penurunan Kadar Glukosa Darah Tikus

Hari ke-42 : Selisih kadar glukosa darah setelah induksi (hari ke-35) dikurangi dengan kadar glukosa darah hari ke-42

Hari ke-49 : Selisih kadar glukosa darah setelah induksi (hari ke-35) dikurangi dengan kadar glukosa darah setelah induksi hari ke-49

Uji analisis sidik ragam (ANSIRA) dilakukan untuk mengetahui apakah ada perbedaan signifikan antara ekstrak etanol umbi bawang dayak dosis $500 \mathrm{mg} / \mathrm{kg} \mathrm{BB}, 750$ $\mathrm{mg} / \mathrm{kg} \mathrm{BB}, 1000 \mathrm{mg} / \mathrm{kg} \mathrm{BB}$ yang digunakan, kontrol negatif ( $\mathrm{Na} \mathrm{CMC} \mathrm{0,5 \% ),} \mathrm{kontrol}$ positif sebagai pembanding (metformin). Hasil tersebut dapat dilihat pada Tabel 2, sampai Tabel 5. 
Hasil statistik menunjukkan adanya perbedaan yang signifikan antar kelompok perlakuan terhadap selisih penurunan kadar glukosa darah hewan uji pada hari ke-42. Hal tersebut dapat dibuktikan dengan melihat nilai $F_{\text {hitung }}$ yang lebih besar dari $F_{\text {tabel }}(\alpha=0,05)$ seperti pada Tabel 2. dibawah ini:

Tabel 2. Data Statistik Penurunan Kadar Glukosa Darah Setelah Perlakuan Hari Ke-42

\begin{tabular}{ccccccc}
\hline Sumber & Derajat & Jumlah & Kuadrat & F & \multicolumn{2}{c}{ F tabel } \\
\cline { 6 - 7 } Keragaman & Bebas & Kuadrat & Tengah & hitung & $\mathbf{5 \%}$ & $\mathbf{1 \%}$ \\
\hline Kelompok & 4 & 12077,84 & 3019,46 & 0,80 & 3,01 & 4,77 \\
Perlakuan & 4 & 106610,64 & 26652,66 & 7,13 & 3,01 & 4,77 \\
Galat & 16 & 59793,76 & 3737,11 & & & \\
\hline Total & 24 & 178482,24 & & & & \\
\hline
\end{tabular}

Oleh karena itu dilakukan uji lanjut Duncan dengan melihat hasil keragaman koefisien yang lebih dari 10\%. Hasil uji lanjut Duncan dapat dilihat pada Tabel 3.

Tabel 3. Hasil Uji Lanjut Duncan Penurunan Kadar Glukosa Darah Setelah Perlakuan Hari ke 42

\begin{tabular}{lc}
\hline \multicolumn{1}{c}{ Perlakuan } & Rerata \\
\hline Kontrol Negatif & $-14,8^{\mathrm{a}}$ \\
Kontrol Positif & $133,8^{\mathrm{b}}$ \\
Ekstrak 1000 mg/kg BB & $140,6^{\mathrm{b}}$ \\
Ekstrak 750 mg/kg BB & $152^{\mathrm{b}}$ \\
Ekstrak 500 mg/kg BB & $160,8^{\mathrm{b}}$ \\
\hline
\end{tabular}

Hasil statistik menunjukkan adanya perbedaan yang signifikan antar kelompok perlakuan terhadap selisih penurunan kadar glukosa darah hewan uji pada hari ke-49. Hal tersebut dapat dibuktikan dengan melihat nilai $F_{\text {hitung }}$ yang lebih besar dari $F_{\text {tabel }}(\alpha=0,05)$ seperti pada Tabel 4. dibawah ini:

Tabel 4. Data Statistik Penurunan Kadar Glukosa Darah Setelah Perlakuan Hari Ke-49

\begin{tabular}{ccccccc}
\hline Sumber & Derajat & Jumlah & Kuadrat & F & \multicolumn{2}{c}{ F tabel } \\
\cline { 6 - 7 } Keragaman & Bebas & Kuadrat & Tengah & hitung & $\mathbf{5 \%}$ & $\mathbf{1 \%}$ \\
\hline Kelompok & 4 & 40210,56 & 10052,64 & 0,92 & 3,01 & 4,77 \\
Perlakuan & 4 & 272493,36 & 68123,34 & 6,26 & 3,01 & 4,77 \\
Galat & 16 & 173981,84 & 10873,86 & & & \\
\hline Total & 24 & 486685,76 & & & & \\
\hline
\end{tabular}

Oleh karena itu dilakukan uji lanjut Duncan dengan melihat hasil keragaman koefisien yang lebih dari 10\%. Hasil uji lanjut Duncan dapat dilihat pada Tabel 5. 
Tabel 5. Hasil Uji Lanjut Duncan Penurunan Kadar Glukosa Darah Setelah Perlakuan Hari ke 49

\begin{tabular}{lc}
\hline \multicolumn{1}{c}{ Perlakuan } & Rerata \\
\hline Kontrol Negatif & $-49^{\mathrm{a}}$ \\
Ekstrak 1000 mg/kg BB & $948^{\mathrm{b}}$ \\
Ekstrak 500 mg/kg BB & $1072^{\mathrm{b}}$ \\
Kontrol Positif & $1087^{\mathrm{b}}$ \\
Ekstrak 750 mg/kg BB & $1104^{\mathrm{c}}$ \\
\hline
\end{tabular}

\section{Pembahasan}

Ekstrak kental umbi bawang dayak (Eleutherine bulbosa (Mill.) Urb.) diidentifikasi secara kualitatif untuk mengetahui kandungan senyawa kimia yang terkandung dalam ekstrak tersebut. Berdasarkan hasil uji fitokimia dapat dikatakan bahwa ekstrak umbi bawang dayak mengandung senyawa-senyawa kimia yaitu alkaloid, flavonoid, saponin, tanin dan fenolik.

Hasil pengukuran kadar glukosa darah awal terlihat bahwa kadar glukosa semua perlakuan rata-rata berkisar antara 80,8-120,6 mg/dL yang menunjukkan seluruh tikus memiliki kadar glukosa darah normal, berdasarkan literatur kadar glukosa darah normal tikus Wistar berkisar antara $50-135 \mathrm{mg} / \mathrm{dL}$. Nilai indeks obesitas Lee tikus pada lampiran 3 yaitu >0,3 yang artinya tikus telah mengalami obesitas. Kadar glukosa darah setelah induksi streptozotocin yaitu 258-386,2 mg/dL yang menunjukkan seluruh tikus mengalami kondisi diabetes (tikus dinyatakan diabetes apabila kadar glukosa darah $>200 \mathrm{mg} / \mathrm{dL}$ ). Streptozotocin (STZ) sering digunakan sebagai induksi insulin-dependent dan non-insulindependent diabetes melitus pada hewan uji karena selektif merusak sel beta pankreas. STZ bekerja langsung pada sel beta pankreas dengan aksi sitotoksiknya dimediatori oleh reactive oxygen species (ROS) sehingga dapat digunakan sebagai induksi diabetes melitus. STZ sebagai agen diabetonik dapat memicu peningkatan produksi radikal bebas berlebih dan menyebabkan stres oksidatif. ${ }^{65}$

Berdasarkan hasil yang diperoleh terhadap penurunan kadar glukosa darah tikus putih jantan yang dianalisis secara statistik dengan Analisis Sidik Ragam (ANSIRA) dan dilanjutkan dengan uji lanjut Duncan pada hari ke-42 memperlihatkan adanya perbedaan signifikan dengan hasil signifikan $\mathrm{F}_{\text {hitung }}>\mathrm{F}_{\text {tabel. }}$ Pengujian dilanjutkan dengan uji lanjut Duncan untuk melihat perbedaan bermakna pada kelompok perlakuan. Berdasarkan hasil uji lanjut Duncan (Tabel 3) menunjukkan bahwa penurunan kadar glukosa untuk kelompok II kontrol negatif yang diberikan $\mathrm{Na}$ CMC $0,5 \%$ berbeda signifikan dengan kelompok III kontrol positif yang diberikan suspensi metformin. Hal ini menunjukkan bahwa pada kelompok II kontrol negatif tidak terdapat penurunan kadar glukosa darah yang signifikan dibandingkan dengan kelompok III kontrol posititf yang diberikan suspensi metformin karena hanya diberikan pembawa suspensi $\mathrm{Na}$ CMC 0,5\% yang bersifat netral dan tidak mempengaruhi kadar glukosa darah pada tikus.

Penurunan kadar glukosa darah kelompok IV yang diberikan ekstrak umbi bawang dayak dosis $500 \mathrm{mg} / \mathrm{kg}$ BB berbeda signifikan dengan kelompok II kontrol negatif yang diberikan $\mathrm{Na}$ CMC 0,5\% dan berbeda tidak signifikan dengan kelompok III kontrol positif yag diberikan suspensi metformin. Hal ini menunjukkan bahwa kelompok IV yang diberikan ekstrak umbi bawang dayak dosis $500 \mathrm{mg} / \mathrm{kg}$ BB dapat menurunkan kadar glukosa darah yang sebanding dengan kelompok III kontrol positif yang diberikan suspensi metformin. Hal ini disebabkan karena kandungan senyawa ekstrak umbi bawang dayak dosis $500 \mathrm{mg} / \mathrm{kg}$ BB sudah mampu berikatan dengan reseptor sehingga memiliki aktivitas penurunan glukosa darah yang sebanding dengan kontrol positif. 
Penurunan kadar glukosa darah kelompok $\mathrm{V}$ yang diberikan ekstrak umbi bawang dayak dosis $750 \mathrm{mg} / \mathrm{kg}$ BB berbeda signifikan dengan kelompok II kontrol negatif yang diberikan Na CMC 0,5\% dan berbeda tidak signifikan dengan kelompok III kontrol positif yang diberikan suspensi metformin. Hal ini juga menunjukkan bahwa kelompok $\mathrm{V}$ yang diberikan ekstrak umbi bawang dayak dosis $750 \mathrm{mg} / \mathrm{kg}$ BB dapat menurunkan kadar glukosa darah yang sebanding dengan kelompok III kontrol positif yang diberikan suspensi metformin. Hal ini disebabkan karena kandungan senyawa ekstrak umbi bawang dayak dosis $750 \mathrm{mg} / \mathrm{kg}$ BB sudah mampu berikatan dengan reseptor sehingga memiliki aktivitas penurunan glukosa darah yang sebanding dengan kontrol positif.

Penurunan kadar glukosa darah kelompok VI ekstrak umbi bawang dayak dosis 1000 $\mathrm{mg} / \mathrm{kg}$ BB berbeda signifikan dengan kelompok II kontrol negatif yang diberikan $\mathrm{Na}$ CMC 0,5\% dan berbeda tidak signifikan dengan kelompok III kontrol positif yang diberikan suspensi metformin. Hal ini juga menunjukkan bahwa kelompok VI yang diberikan ekstrak umbi bawang dayak dosis $1000 \mathrm{mg} / \mathrm{kg}$ BB dapat menurunkan kadar glukosa darah yang sebanding dengan kelompok III kontrol positif yang diberikan suspensi metformin. Hal ini disebabkan karena kandungan senyawa ekstrak umbi bawang dayak dosis $1000 \mathrm{mg} / \mathrm{kg} \mathrm{BB}$ sudah mampu berikatan dengan reseptor sehingga memiliki aktivitas penurunan glukosa darah yang sebanding dengan kontrol positif. Senyawa-senyawa yang terkandung pada umbi bawang dayak yang diduga dapat menurunkan kadar glukosa darah adalah Alkaloid yang terbukti memiliki kemampuan meregenerasi sel $\beta$ pankreas yang rusak. Adanya perbaikan pada jaringan pankreas, maka akan terjadi peningkatan jumlah insulin di dalam tubuh sehingga glukosa darah akan masuk ke dalam sel dan terjadi penurunan kadar glukosa darah dalam tubuh. ${ }^{23}$ Saponin juga dapat menurunkan kdar glukosa darah dengan menghambat penyerapan glukosa di usus halus dan menghambat pengosongan lambung. Melambatnya pengosongan lambung, maka absorbsi makanan akan semakin lama, dan kadar glukosa darah akan mengalami perbaikan. ${ }^{25}$ Flavonoid mampu meningkatkan aktivitas enzim antioksidan dan mampu meregenerasi sel-sel $\beta$ pankreas yang rusak sehingga defisiensi insulin dapat diatasi dan dapat memperbaiki sensitivitas reseptor insulin. ${ }^{30}$ Tanin juga dapat berfungsi sebagai astringent atau pengkelat yang dapat mengkerutkan membran epitel usus halus sehingga mengurangi penyerapan sari-sari makanan akibatnya dapat menghambat asupan glukosa dan laju peningkatan glukosa darah menjadi tidak terlalu tinggi. ${ }^{33}$

Berdasarkan hasil yang diperoleh terhadap penurunan kadar glukosa darah tikus putih jantan yang dianalisis secara statistik dengan Analisis Sidik Ragam (ANSIRA) dan dilanjutkan dengan uji lanjut Duncan pada hari ke-49 memperlihatkan adanya perbedaan signifikan dengan hasil signifikan $F_{\text {hitung }}>F_{\text {tabel. }}$. Pengujian dilanjutkan dengan uji lanjut Duncan untuk melihat perbedaan bermakna pada kelompok perlakuan. Berdasarkan hasil uji lanjut Duncan (Tabel 5) menunjukkan bahwa penurunan kadar glukosa darah kelompok II kontrol negatif yang diberikan Na CMC berbeda signifikan dengan kelompok III kontrol positif yang diberikan suspensi metformin. Hal ini berarti bahwa kelompok II kontrol negatif yang diberikan $\mathrm{Na}$ CMC $0,5 \%$ masih memiliki efek yang sama pada hari ke-42 yaitu tidak dapat menurunkan kadar glukosa darah secara signifikan karena hanya diberikan suspensi $\mathrm{Na} \mathrm{CMC}$ 0,5\% yang tidak berpengaruh terhadap kadar glukosa darah.

Penurunan kadar glukosa untuk kelompok IV yang diberikan ekstrak umbi bawang dayak dosis $500 \mathrm{mg} / \mathrm{kg}$ BB berbeda signifikan dengan kelompok II kontrol negatif yang diberikan $\mathrm{Na}$ CMC 0,5\% dan berbeda tidak signifikan dengan kelompok III kontrol positif yang diberikan suspensi metformin. Hal ini menunjukkan bahwa kelompok IV ekstrak umbi bawang dayak dosis $500 \mathrm{mg} / \mathrm{kg}$ BB masih memiliki efek yang sama pada hari ke-42 yaitu memiliki aktivitas penurunan glukosa darah yang sebanding dengan kelompok III kontrol positif yang diberikan suspensi metformin. Hal ini disebabkan karena kandungan 
senyawa ekstrak umbi bawang dayak dosis $500 \mathrm{mg} / \mathrm{kg}$ BB masih mampu berikatan dengan reseptor sehingga memiliki aktivitas penurunan glukosa darah yang sebanding dengan kontrol positif.

Penurunan kadar glukosa darah kelompok $\mathrm{V}$ yang diberikan ekstrak umbi bawang dayak dosis $750 \mathrm{mg} / \mathrm{kg}$ BB berbeda signifikan dengan kelompok III kontrol positif yang diberikan suspensi metformin (lebih tinggi dari kontrol positif). Hal ini menunjukkan bahwa ekstrak umbi bawang dayak dosis $750 \mathrm{mg} / \mathrm{kg}$ BB sudah memiliki efektivitas yang lebih baik dari kontrol positif. Hal ini diduga karena kandungan senyawa aktif yang sudah cukup dalam darah untuk menurunkan kadar glukosa darah pada tikus putih jantan.

Penurunan kadar glukosa darah kelompok VI yang diberikan ekstrak umbi bawang dayak dosis $1000 \mathrm{mg} / \mathrm{kg}$ BB berbeda signifikan dengan kelompok II kontrol negatif yang diberikan $\mathrm{Na} \mathrm{CMC}$ dan berbeda tidak signifikan dengan kelompok III kontrol positif yang diberikan suspensi metformin. Hal ini menunjukkan bahwa kelompok VI yang diberikan ekstrak umbi bawang dayak dosis $1000 \mathrm{mg} / \mathrm{kg}$ BB juga masih memiliki efek yang sama pada hari ke-42 yaitu memiliki aktivitas penurunan glukosa darah yang sebanding dengan kelompok III kontrol positif yang diberikan suspensi metformin. Hal ini disebabkan karena kandungan senyawa ekstrak umbi bawang dayak dosis $1000 \mathrm{mg} / \mathrm{kg}$ BB masih mampu berikatan dengan reseptor sehingga memiliki aktivitas penurunan glukosa darah yang sebanding dengan kontrol positif.

Berdasarkan hasil dan pembahasan di atas, dapat diketahui bahwa ekstrak etanol umbi bawang dayak dapat menurunkan kadar glukosa darah. Hal ini dapat dilihat pada hasil statistik uji Analisis Sidik Ragam yang dilanjutkan dengan uji lanjut Duncan secara umum yang menunjukkan bahwa ketiga variasi dosis ekstrak etanol umbi bawang dayak yaitu $500 \mathrm{mg} / \mathrm{kg} \mathrm{BB}, 750 \mathrm{mg} / \mathrm{kg} \mathrm{BB}, 1000 \mathrm{mg}$ berada dalam satu wilayah dengan kontrol positif, artinya memiliki efek yang sebanding dengan kontrol positif. Meskipun pada hari ke-49 ekstrak etanol umbi bawang dayak dosis $750 \mathrm{mg} / \mathrm{kg}$ BB menunjukkan efek yang lebih baik dari kontrol positif. Sehingga dapat disimpulkan bahwa ekstrak etanol umbi bawang dayak memiliki efek dalam menurunkan kadar glukosa darah pada tikus diabetes melitus tipe 2 yang obesitas.

\section{KESIMPULAN}

Berdasarkan hasil penelitian uji efektivitas antidiabetes ekstrak etanol umbi bawang dayak (Eleutherine bulbosa (Mill.) Urb.) terhadap penurunan kadar glukosa darah tikus putih jantan diabetes melitus tipe 2 yang obesitas dapat disimpulkan sebagai berikut:

1. Ekstrak etanol umbi bawang dayak (Eleutherine bulbosa (Mill.) Urb.)dosis $500 \mathrm{mg} / \mathrm{kg}$ BB, $750 \mathrm{mg} / \mathrm{kg} \mathrm{BB}, 1000 \mathrm{mg} / \mathrm{kg}$ BB memiliki efektivitas antidiabetes pada tikus putih jantan (Rattus norvegicus) diabetes melitus tipe 2 yang obesitas.

2. Ekstrak umbi bawang dayak dosis $500 \mathrm{mg} / \mathrm{kg}$ BB merupakan dosis yang paling efektif dalam penurunan kadar glukosa darah.

\section{DAFTAR PUSTAKA}

1. Achjar Henny, dkk., 2014. Hubungan Obesitas Dengan Kadar Gula DarahSewaktu Pada Usia Dewasa Awal Di Wilayah Kerja Puskesmas 1 Abang Tahun 2014. POLTEKKES Denpasar. Hal.2

2. Hermawan, Guntur A., 1991. Komplikasi Obesitas dan Usaha Penanggulangannya. Surakarta. Hal.5-6

3. Trihono., 2013. Riset Kesehatan Dasar. Badan Penelitian Dan Pengembangan Kesehatan Kementrian Kesehatan RI. Jakarta. Diakses 12 Mei 2015. Hal.3 
4. Toft-Nielsen, M., Madsbad, S., Holst J., 2001. Determinants of the effectiveness of glucagon-like peptide-1 in type 2 diabetes. J Clin Endocrinol Metab. 86(8): 3853-60. Hal.13

5. Departemen Kesehatan., 2005. Pharmaceutical Care untuk Penyakit Diabetes Melitus. Hal.8

6. Soewondo, P., 2007. Pemantauan pengendalian Diabetes Melitus. Dalam Penatalaksanaan Diabetes Melitus terpadu. Jakarta: Balai Penerbit FKUI. Hal.21

7. Kementerian Kesehatan., 2010. Petunjuk Teknis Pengukuran Faktor Resiko Diabetes Melitus. Hal.12

8. Irawan, Dedi., 2010. Prevalensi dan Faktor Resiko Kejadian Diabetes Melitus Tipe 2 di Daerah Urban Indonesia (Analisa Data Sekunder Riskesdas 2007). Thesis Universitas Indonesia. Hal.21-23

9. S.H, Bintari., K, Nugraheni., 2012. Penurunan Kadar Gula Darah Akibat Pemberian Extra Virgin Olive Oil (Studi pada Tikus Galur Sprague Dawley yang Diinduksi Pakan Tinggi Lemak). Universitas Negeri Semarang. Semarang. Hal.12

10. Anief, Moch., Ilmu Meracik Obat Teori dan Praktek. Yogyakarta : Gadjah Mada University Press, 1995. Hal.35

11. Hidayat, S., 2005. Ramuan Tradisional ala 12 etnis Indonesia. Penebar swadaya, Jakarta. Hal.22

12. Galingging, Y, R., 2010. Bawang dayak (Eluetherine palmifolia) Sebagai Tanaman Obat Multifungsi. http://kalteng.litbang.deptan.go.id/data/bawang-dayak.pdf (diakses 5 Juni 2015). Hal.4

13. Raga, Y, P., 2012. Respons Pertumbuhan dan Hasil Bawang Sabrang (Eluetherine americana Merr.) Pada Beberapa Jarak Tanam dan Berbagai Tingkat Pemotong Umbi Bibit, Jurnal Online Agroteknologi, diakses pada tanggal 5 Juni 2015. Hal.35

14. Megawati, Y.S., 2005. "Pengujian Daya Hambat Ekstrak Metanol Bawang Dayak (Eleutherine palmifolia (L.) Merr) Terhadap Pertumbuhan Bakteri Staphylococcus aureus dan Bacillus substilis", KTI Akademi Farmasi Pontianak. Yayasan Rumah Sakit Islam. Pontianak. Hal.6

15. Firdaus, R., 2006. Telaah Kandungan Kimia Ekstrak Metanol Umbi Bawang Tiwai (Eluetherine americana (Aubl.) Merr.). Skripsi. Institut Teknologi Bandung. Bandung. Hal.28-30

16. Andi, E Febrina., Astawan, M., Wresdiyati, T., Yuliana, N.D., 2013. Kapasitas Antioksidan dan Inhibitor Alfa Glukosidase Ekstrak Umbi Bawang Dayak. Institut Pertanian Bogor. Bogor. Hal.5

17. Evacuasiany, Endang., Djojosoewarno, Pinandojo., Hendrik., 2014. Pengaruh Ekstrak Bawang Berlian (Eleutherine americana Merr) Terhadap Penurunan Kadar Glukosa Darah Pada Mencit Swiss Webster Jantan Model Hiperglikemia. Universitas Kristen Maranatha. Bandung

18. Yusni A, Muhammad., 2008. Perbedaan Pengaruh Pemberian Fraksi Etanolik Bawang Dayak (Eleutherine palmifolia L. Merr) Dengan 5-Fluorouracil Terhadap Penghambatan Pertumbuhan Galur Sel Karsinoma Kolon HT29 dan Ekspresi p53 Mutan. Fakultas Kedokteran Universitas Sebelas Maret. Surakarta.

19. Kementerian Riset Teknologi dan Penddikan Tinggi Universitas Tadulako., 2015. UPT. Sumber Daya Hayati Sulawesi. Palu. Hal.1-2

20. Firdaus, Tazkiyatul., 2014. Efektivitas Ekstrak Bawang Dayak (Eleutherine palmifolia) Dalam Menghambat Pertumbuhan Bakteri Staphylococcus aureus. Universitas Islam Negeri Syarif Hidayatullah. Jakarta. Hal.24

21. Harbone, J.B., 1987. Metode Fitokimia: Penuntun Cara Modern Menganalisis Tumbuhan. Institut Teknologi Bandung (ITB). Bandung. Hal 56-70 
22. Suryani, N., T. Endang., Aulanni'am., 2013. Pengaruh Ekstrak Metanol Biji Mahoni Terhadap Peningkatan Kadar Insulin, Penurunan Ekspresi TNF- $\alpha$ dan Perbaikan Jaringan Pankreas Tikus Diabetes. Jurnal Kedokteran Brawijaya, Vol. 27, No. 3. Hal. 9,10

23. Putrianti, R., 2013. Skrining Fitokimia dan Aktivitas Antioksidan Ekstrak Rumput Laut Sargassum duplicatum dan Turbinaria Ornate dari Jepara [tesis]. Fakultas Perikanan dan Ilmu Kelautan Universitas Diponegoro. Semarang. Hal.83

24. Bruneton, J., 1999, pharmacognosy, Phytochemistry, Medicinal Plant, 2 nd edition, Lavoiser. New York. Hal.72-73

25. Matsuda, T., Nakamura, T., Nakako, K., Arai, T., Katsuki, M., Heike, T., Yokota, T., 1999. STAT3 activation is sufficient to maintain an undifferentiated state of mouse embryonic stem cells. Embo J. Hal.61. 